\title{
Enhanced Seismic Structural Reliability on Reinforced Concrete Buildings by Using Buckling Restrained Braces
}

\author{
Victor Baca, ${ }^{1}$ Juan Bojórquez $\mathbb{D}^{1},{ }^{1}$ Edén Bojórquez $\mathbb{D}^{1},{ }^{1}$ Herian Leyva, \\ Alfredo Reyes-Salazar, ${ }^{1}$ Sonia E. Ruiz ${ }^{(D)}{ }^{2}$ Antonio Formisano, ${ }^{3}$ Leonardo Palemón, ${ }^{4}$ \\ Robespierre Chávez, ${ }^{1}$ and Manuel Barraza $\mathbb{D D}^{5}$ \\ ${ }^{1}$ Facultad de Ingeniería, Universidad Autónoma de Sinaloa, Culiacán 80040, Mexico \\ ${ }^{2}$ Instituto de Ingeniería, Universidad Nacional Autónoma de México, México 04510, Mexico \\ ${ }^{3}$ Department of Structures for Engineering and Architecture, University of Naples, Naples 80125, Italy \\ ${ }^{4}$ Departamento de Ingeniería Civil, Universidad Autónoma del Carmen, Cd. del Carmen 24180, Mexico \\ ${ }^{5}$ Facultad de Ingeniería, Arquitectura y Diseño, Universidad Autónoma de Baja California, Ensenada 22860, Mexico
}

Correspondence should be addressed to Juan Bojórquez; jbm_squall_cloud@hotmail.com

Received 5 August 2020; Revised 24 December 2020; Accepted 28 January 2021; Published 9 February 2021

Academic Editor: Francisco Beltran-Carbajal

Copyright (c) 2021 Victor Baca et al. This is an open access article distributed under the Creative Commons Attribution License, which permits unrestricted use, distribution, and reproduction in any medium, provided the original work is properly cited.

The control of vibrations and damage in traditional reinforced concrete (RC) buildings under earthquakes is a difficult task. It requires the use of innovative devices to enhance the seismic behavior of concrete buildings. In this paper, we design RC buildings with buckling restrained braces (BRBs) to achieve this objective. For this aim, three traditional RC framed structures with 3,6 , and 9 story levels are designed by using the well-known technique nondominated sorting genetic algorithm (NSGA-II) in order to reduce the cost and maximize the seismic performance. Then, equivalent RC buildings are designed but including buckling restrained braces. Both structural systems are subjected to several narrow-band ground motions recorded at soft soil sites of Mexico City scaled at different levels of intensities in terms of the spectral acceleration at first mode of vibration of the structure $S_{a}\left(T_{1}\right)$. Then, incremental dynamic analysis, seismic fragility, and structural reliability in terms of the maximum interstory drift are computed for all the buildings. For the three selected structures and the equivalent models with BRBs, it is concluded that the annual rate of exceedance is considerably reduced when BRBs are incorporated. For this reason, the structural reliability of the RC buildings with BRBs has a better behavior in comparison with the traditional reinforced concrete buildings. The use of BRBs is a good option to improve strength and seismic behavior and hence the structural reliability of RC buildings subjected to strong earthquake ground motions.

\section{Introduction}

In the past few years, an extensive amount of buildings has suffered damage due to medium and large earthquakes. Structural systems have evolved in order to reduce seismic damage. Nowadays, one of the most used structural systems is that based on reinforced concrete frames. Reinforced concrete buildings have been frequently used; nevertheless, the main disadvantage of them is the difficulty to be repaired after the occurrence of an earthquake. Furthermore, RC structures located on seismic zones usually are subjected to large peak interstory drift displacements produced by the lateral loads.
Since the seismic design regulations recommend the control of maximum interstory drift as the main engineering demand parameter in order to achieve a good structural performance as Krawinkler and Gupta suggest [1], it is necessary to reduce the peak drift demands in RC buildings. The displacement on traditional concrete buildings can be reduced by means of concentrically braces. The objective of the braces in structural frames is to increase the stiffness and to reduce the lateral displacements due to earthquakes $[2,3]$. In spite of the advantages of typical braced frames, several studies have highlighted that frequent damage has been observed on this type of structural system in past earthquakes such as the 1985 Mexico 
earthquake, 1989 Loma Prieta earthquake, 1994 Northridge earthquake, and 1995 Hyogo-ken Nanbu earthquake, among others [4-9], as it was indicated by Sabelli et al. [10]. In particular, the unsymmetrical properties in tension and compression and the large strength deterioration in compression reduce considerably the performance of the braces. In order to have the same mechanical properties in tension and compression of the braces, a new type of brace named buckling restrained brace which consists of a ductility steel core that is forced to have similar yield in tension and compression by restrained the buckling has been suggested [11-17]. Several experimental tests have demonstrated that the cyclic behavior of the BRBs is stable and almost bilinear; in particular, Palazzo et al. [18] concluded that it is feasible to design buckling restrained braces that are efficient, robust, virtually maintenancefree, durable, reasonably cheap, easy to produce, and made of basic and easily replaceable materials. For this reason, although the seismic response of reinforced concrete frames with buckling restrained braces has been studied, usually $2 \mathrm{D}$ systems are considered for the dynamic analyses; moreover, the advantages of BRBs on $\mathrm{RC}$ buildings in terms of structural fragility and reliability are not commonly assessed. Motivated by the need to observe the advantages of BRBs in the seismic performance in terms of structural fragility and reliability of $3 \mathrm{D}$ reinforced concrete framed buildings, in the present study, the seismic performance of 3D RC buildings and equivalent 3D RC structures with BRBs is assessed. For the purpose of this work, three structural RC buildings with 3, 6, and 9 stories are designed according to the Mexico City Seismic Design Provisions (MCSDP) [19]. In addition, three equivalent concrete buildings with BRBs are designed. It is important to say that for the seismic design of all the buildings, the NSGA-II approach $[20,21]$ is used in order to reduce the cost and increase the structural capacity in accordance with the MCSDP. The 3D framed buildings in both type of structural systems are subjected to 30 ground motion records obtained from soft soil sites of Mexico City scaled at different spectral accelerations at first mode of vibration of the structure. Thus, a total of 3,600 seismic analyses have been performed. The numerical results of the analyses suggest that the seismic performance of reinforced concrete buildings with buckling restrained braces is superior to that of the structural behavior of traditional buildings indicating the advantages of this structural system. For this reason, $\mathrm{BRBs}$ can increase considerably the structural reliability when they are incorporated in reinforced concrete frames. Moreover, the damage in the buildings with BRBs is concentrated in the braces which can be replaced after the occurrence of an earthquake. It is important to say that although soil structure interaction was not taken into account, notice that similar conclusions are expected because this effect increases the period of vibration of a building [22, 23].

\section{Buckling Restrained Braces}

The innovative buckling restrained braces are devices used as seismic energy absorption elements with the aim of reducing the damage in a structure under strong earthquake events. They consists of a steel section enclosed in a tubular or cylindrical case filled with concrete or mortar. Figure 1 shows the topology and components of this brace [11, 24], which makes it possible to take advantage of the full capacity of steel core and to obtain a symmetrical and highly stable cyclic behavior in comparison with conventional braces. In addition, BRBs can be easily replaced in case of damage.

Different experimental studies on this type of devices have been carried out. Terán-Gilmore and Virto-Cambray [25] performed cyclic test at multiple BRBs using circular tube or angle steel cores concluding that both developed stable hysteretic behavior and similar resistance to both compression and tension. Khampanit et al. [2] proposed an energy-based design methodology by comparing experimental studies between a reinforced concrete bare frame and a reinforced concrete braced frame. Guerrero et al. [26] carried out a comparative study between two 5-story steel frames with and without BRB at 1/10 scale factor under narrow-band seismic records obtained in Mexico City. The results demonstrated a considerable decrease in terms of displacements, maximum interstory drift, and floor accelerations for braced frames, as well as an increase of stiffness and damping of the system. Similarly, studies have been carried out on new methods to adequately model this type of braces. Rahnavard et al. [27] compared hysteresis curves of experimental studies with a simple numerical model in order to avoid large computational time for the analyses. In addition, they have used this type of brace for retrofit or strengthening of concrete buildings [28]. In this study, a considerable difference is observed in lateral resistance, cyclic behavior, and energy dissipation capacity. The lateral stiffness that a BRB brings to a floor can be obtained regardless of the core area as shown in the following equation [29]:

$$
\frac{K_{L}}{(A / L)}=\frac{E \cos ^{2} \theta}{\gamma+\eta(1-\gamma)}=\frac{E \cos ^{2} \theta}{L_{R F}},
$$

where $L$ is the total length of the brace, $E$ is the elastic modulus, $\theta$ is the angle of inclination, $L_{c}$ is the length of element without connections, $\gamma$ is the relation between $L_{c}$ and $L, \eta$ is the relation between average axial strains of outside and inside the core, and $L_{R F}$ is a factor that considers the region of higher axial stiffness at the ends of the brace. Terán-Gilmore and Ruiz-García [30] determined that under the consideration of $L_{c}$, it is equal to half value of $L$, and that the average area outside the core is three times the area of core; $L_{R F}$ is equal to 0.667 . Therefore, the actual stiffness that BRB brings to the system depends on the difference between the core and connection areas. Through this type of mechanism, the reinforced concrete braced and unbraced buildings were designed using the NSGA-II approach as explained below. Finally, the seismic reliability when both structural systems are subjected to narrow-band motions recorded in Mexico City is compared.

\section{Methodology}

3.1. Seismic Design of the RC Models Using NSGA-II. Currently, there are a large number of studies on the application of optimization techniques for structural design, 


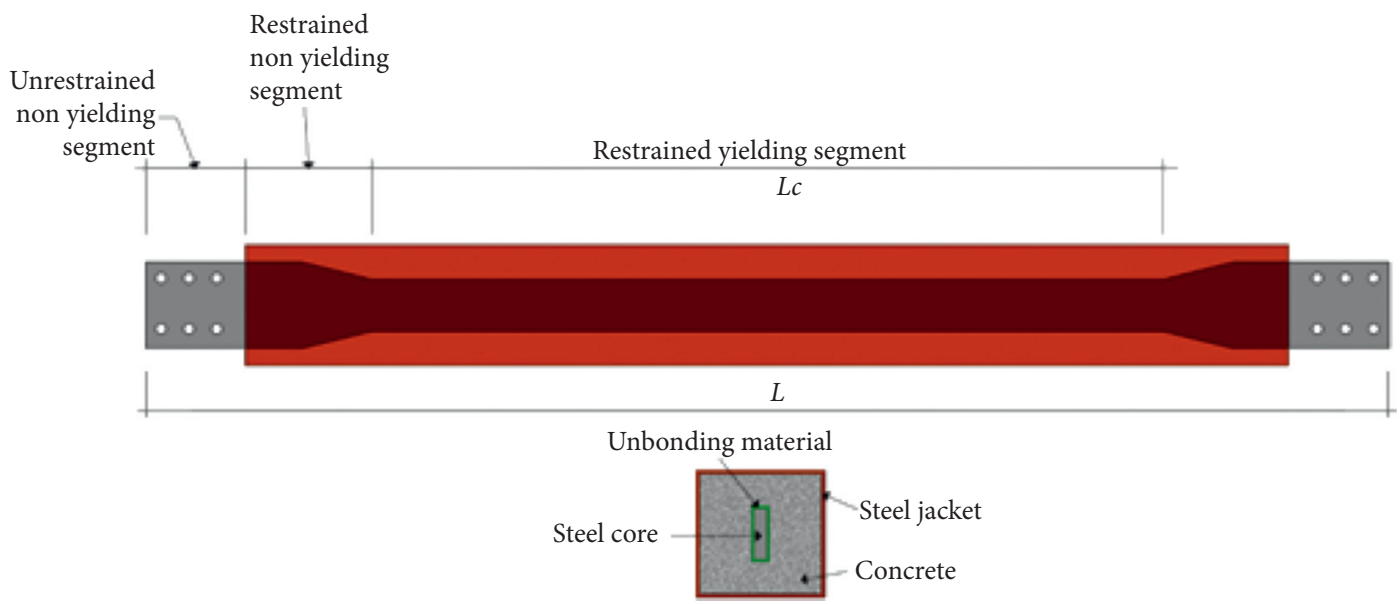

FiguRE 1: Buckling restrained brace parts and cross section components.

especially using genetic algorithms [31]. The aim of this approach is to generate a random population of solutions, classifying them according to their goodness as a solution to the problem using a fitness function. The closest solutions that satisfy the problem are used to obtain new solutions through a crossover procedure, maintaining the best characteristics of each solution. This procedure is repeated up to the desired cycles or generation number, and finally it is able to find optimal results. A typical genetic algorithm is based on the following parameters:

(1) Fitness function: it consists of creating one or more functions that adequately evaluate the ability of each solution to solve the problem. In addition, penalties are included in order to eliminate those solutions that do not comply simple requirements, in this case some penalties can be adequate beam-columns connections, excessive or inadequate height of section, and excessive displacement, among others. It is important to classify individuals using these values.

(2) Crossover: it is based on getting new solutions from the best ones. To this aim, each one is represented by a binary codification and the combination of two different codes at any point generates new ones. This exchange is similar to that obtained in sexual reproduction.

(3) Mutation: it consists of generating diversity by the change of a single bit from binary code using a desired probability that determines which solutions mutate.

For seismic design purposes, it is necessary to use a multiobjective optimization technique such as NSGA-II [21]. This method has been useful for the seismic design of $2 \mathrm{D}$ and $3 \mathrm{D}$ framed steel buildings compared with another optimization technique [32], for multiobjective design of green buildings [33]. Furthermore, it has recently been used for the optimal design of structures equipped with semiactive fluid viscous dampers [34].

In this study, three RC buildings with 3, 6, and 9 stories named RC3, RC6, and RC9 and equivalent structural models with BRBs (named RC3-BRB, RC6-BRB, and RC9-BRB) were designed evaluating two fitness functions: the cost and the maximum interstory drift. While the main characteristics of the structural models are shown in Table 1, Figure 2 illustrates a 3D view of the braced building with 6 story levels. Notice that all the buildings were designed under seismic loads corresponding to soft soil sites of Mexico City. It was proposed to use a different section of beam and column for each 3 floors and one BRB section for all the framed buildings.

The full procedure used for the seismic design of the three framed RC buildings is illustrated in Figure 3 (see Leyva et al. [35] for more details about this approach). The same procedure was used for the seismic design of the RC buildings with BRBs.

As it was indicated before, Figure 3 shows a flowchart of the design procedure. In first place, a number of generation and population are proposed; notice that the first generation is randomly created. Then, we proceed to carry out the main parameters of the genetic algorithm, especially, the fitness functions (2) and (3), crossover, and mutation, in order to obtain the individuals of the new generation. This procedure is repeated and better results are expected as the number of generations increases. It is important to mention that the fitness functions were calibrated based on numerous tests of the algorithm.

$$
\begin{aligned}
& F_{1}=I_{\mathrm{MID}} C_{\text {slab }}^{5} C_{d}^{3} C_{\text {con }} C_{s}^{1 / 10}, \\
& F_{2}=C^{1 / 3} C_{\text {slab }}^{5} C_{d}^{3} C_{\text {con }} C_{s}^{1 / 10},
\end{aligned}
$$

where $F_{1}$ and $F_{2}$ are the fitness functions of maximum interstory drift (MID) and cost, respectively. $F_{1}$ has the objective to find the lightest sections comparing MID with a target drift (TD), as shown in the following equation:

$$
I_{\mathrm{MID}}=\frac{\mathrm{TD}}{\mathrm{MID}} \text {. }
$$

With $F_{2}$, it is intended to obtain the most economical sections taking into account the materials and labor cost of the building: 
TABLE 1: Main geometric characteristics of the designed structural models.

\begin{tabular}{lcccccc}
\hline Model & Number of floors & Bay dir. X & Bay dir. Y & Interstory height $(\mathrm{m})$ & Bay length $(\mathrm{m})$ & Total height $(\mathrm{m})$ \\
\hline RC3, RC3-BRB & 3 & 3 & 3 & 3.5 & 7 & 10.5 \\
RC6, RC6-BRB & 6 & 3 & 3 & 3.5 & 7 & 21 \\
RC9, RC9-BRB & 9 & 3 & 3 & 3 & 5 & 27 \\
\hline
\end{tabular}

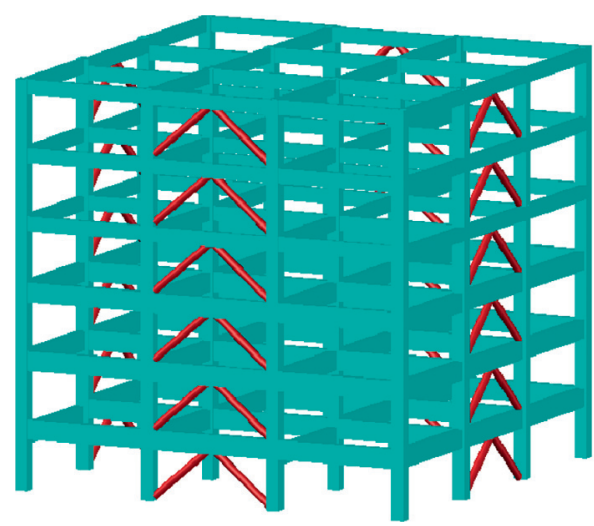

Figure 2: 3D view of the reinforced concrete building with BRBs (model RC-BRB6).

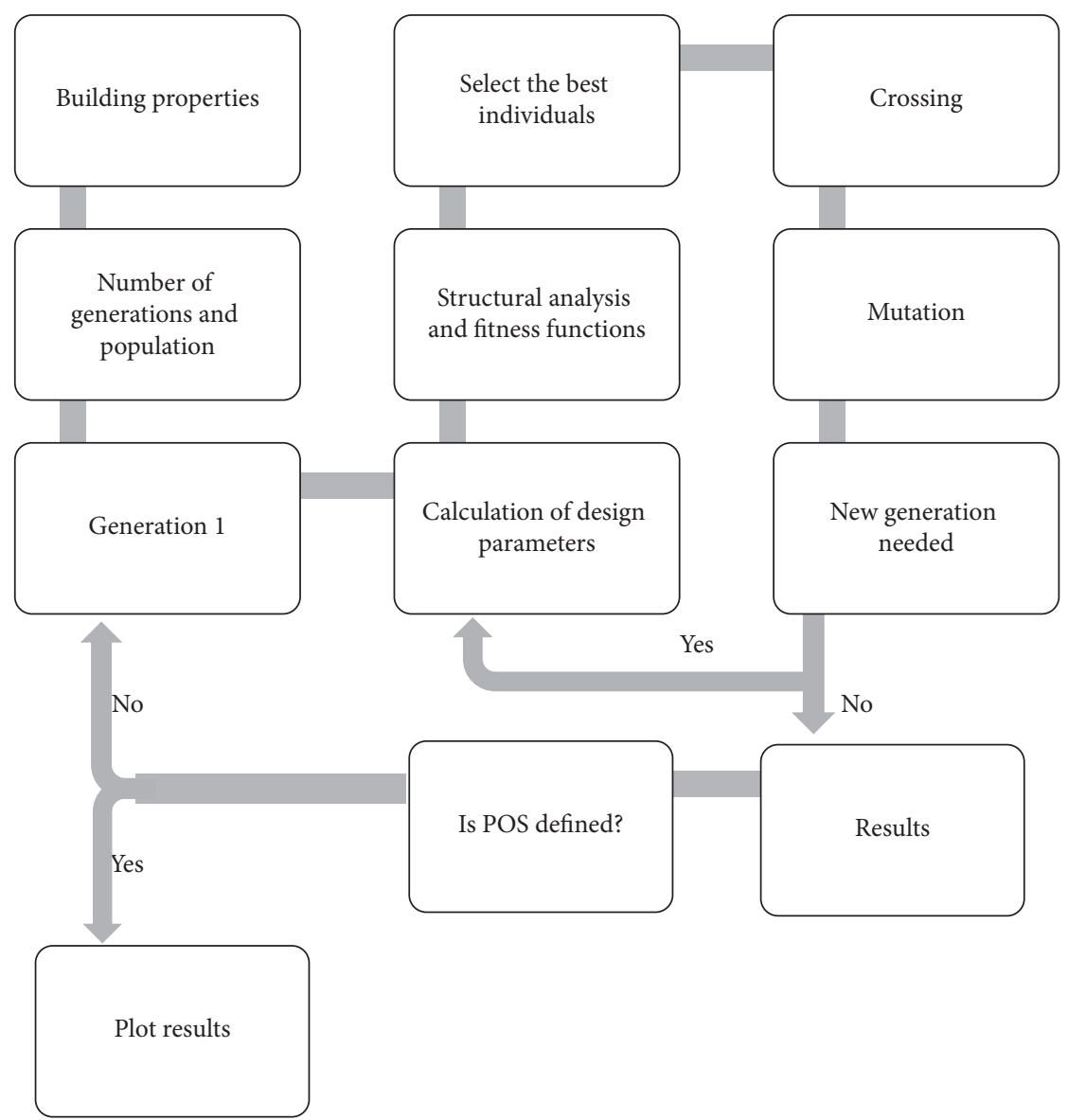

FIGURE 3: Flowchart used for the seismic design of the three-dimensional RC buildings [35]. 


$$
C=C_{r}+C_{c}+C_{l}
$$

where $C_{r}, C_{c}, C_{l}$, and $C$ are reinforcement, concrete, labor, and total costs, respectively.

The other parameters are used as design constraints if the individual does not satisfy the requirements of displacement $\left(C_{d}\right)$, strength $\left(C_{s}\right)$, constructive feasibility of connections $\left(C_{\text {con }}\right)$, and slab thickness $\left(C_{\text {slab }}\right)$.

This procedure was computed several times for each model studied to define the well-known Pareto frontier [21]. Table 2 shows the final sections and the main properties of the structural models obtained.

3.2. Earthquake Ground Motions. For the dynamic analyses of the structural models, thirty narrow-band earthquake ground motions recorded at soft soil sites of Mexico City are used. The soft soil ground motion records were selected because they demand high energy on structures in comparison to firm soil accelerograms $[36,37]$. The ground motions were recorded in sites where the soil period is about two seconds and severe level of damage in structures was observed during the 1985 Mexico City Earthquake. In Table 3, some important characteristics of the records are illustrated. Notice that $P G A$ and $P G V$ denote the peak ground acceleration and velocity, and $t_{D}$ indicates the Trifunac and Brady duration [38].

3.3. Structural Reliability Assessment. The incremental dynamic analysis [39] is used to assess the seismic performance of the RC buildings under narrow-band motions scaled at different intensity levels in terms of spectral acceleration at first mode of vibration of the structure. Next, the wellknown seismic performance-based assessment procedure suggested by the Pacific Earthquake Engineering Center [40] in the United States was employed in this study, which indicates that the mean annual rate of exceeding (MARE) a certain engineering demand parameter $(E D P)$, such as peak interstory drift, in this way exceeding a certain level edp can be computed as follows:

$$
\begin{aligned}
\lambda(E D P>e d p) \cong & \int_{I M} P[E D P>e d p \mid I M=i m] \\
& \cdot\left|d \lambda_{I M}(i m)\right|
\end{aligned}
$$

where IM denotes the ground motion intensity measure (in this study, the spectral acceleration at the first-mode period of vibration was used as $I M)$ and $P[E D P>e d p \mid I M=i m]$ represents the fragility curve which is the conditional probability that a EDP exceeds a certain level of edp given that the $I M$ is evaluated at the ground motion intensity measure level $\mathrm{im}$. Furthermore, $d \lambda_{I M}(\mathrm{im})$ refers to the differential of the seismic hazard curve of the site of interest. In this context, the conditional probability that EDP exceeds a certain level of edp can be obtained using incremental dynamic analyses and estimating probabilistic of the EDP of interest. The second term in equation (6) is represented by the seismic hazard curve, which can be computed from conventional probabilistic seismic hazard analysis, evaluated at the ground motion intensity level $\mathrm{im}$. It is important to note that the ground motion intensity measure plays an important role for assessment of the seismic performance, which is the joint between seismology and earthquake engineering. As stated, $S_{a}\left(T_{1}\right)$ was selected as $I M$ and maximum interstory drift (MID) as EDP in such a way that equation (6) can be expressed as follows:

$$
\begin{aligned}
\lambda(M I D>\operatorname{mid}) \cong & \int_{S_{a}(T)_{1}} P\left[M I D>\operatorname{mid} \mid S_{a}(T)_{1}=s_{a}\right] \\
& \cdot\left|d \lambda_{S_{a}\left(T_{1}\right)}\left(s_{a}\right)\right|
\end{aligned}
$$

where $d \lambda_{S_{a}\left(T_{1}\right)}\left(s_{a}\right)=\lambda_{S_{a}\left(T_{1}\right)}\left(s_{a}\right)-\lambda_{S_{a}\left(T_{1}\right)}\left(s_{a}+d s_{a}\right)$ is the hazard curve differential expressed in terms of $S_{a}\left(T_{1}\right)$. The seismic reliability of the selected RC and RC-BRB structures was evaluated using equation (7) in terms of the maximum interstory drift demands. In the evaluation of the first term in the integrand for the case of maximum interstory drift demands, a lognormal cumulative probability distribution was used [41]. For this reason, the term $P\left[M I D>\operatorname{mid} \mid S_{a}\left(T_{1}\right)=s_{a}\right]$ is analytically evaluated as follows:

$$
\begin{aligned}
& P\left(M I D>\operatorname{mid} \mid S_{a}\left(T_{1}\right)=s_{a}\right) \\
& =1-\Phi\left(\frac{\ln \operatorname{mid}-\widehat{\mu}_{\ln M I D \mid S_{a}\left(T_{1}\right)=s_{a}}}{\widehat{\sigma}_{\ln M I D \mid S_{a}}\left(T_{1}\right)=s_{a}}\right),
\end{aligned}
$$

where $\widehat{\mu}_{\ln M I D \mid S_{a}\left(T_{1}\right)=s_{a}}$ and $\widehat{\sigma}_{\ln M I D \mid S_{a}\left(T_{1}\right)=s_{a}}$ are the geometric mean and standard deviation of the natural logarithm of the $M I D$, respectively, and $\Phi(\cdot)$ is the standard normal cumulative distribution function. It is important to say that Bojórquez et al. [42] suggested the use of $S_{a}\left(T_{1}\right)$ as intensity measure for records having similar values of $N_{p}$ [43].

\section{Comparison of the Seismic Performance of the RC and RC-BRB Structures: Numerical Results}

4.1. Incremental Dynamic Analysis. With the aim to assess and compare the structural fragility and reliability of both selected building models types, the first step is the development of incremental dynamic analysis (IDA) curves. For this aim, the peak interstory drift is computing at different values of the intensity measure $S_{a}\left(T_{1}\right)$ for all the narrowband records under consideration. Note that the Ruaumoko software has been used for the 3600 dynamic analyses. Figure 4 compares the incremental dynamic analysis curves for the structural models RC and RC-BRB. It is observed that 
TABLe 2: Main properties of the six RC building models (dimensions in $\mathrm{cm}$ ).

\begin{tabular}{lcccccc}
\hline Model property & RC3 & RC3-BRB & RC6 & RC6-BRB & RC9 & RC9-BRB \\
\hline Column1 & $55 \times 55$ & $40 \times 40$ & $65 \times 65$ & $55 \times 55$ & $55 \times 55$ & $55 \times 55$ \\
Column2 & & & $65 \times 65$ & $50 \times 50$ & $45 \times 45$ \\
Column3 & & & & $35 \times 45$ \\
Beam1 & $35 \times 65$ & $30 \times 65$ & $45 \times 100$ & $35 \times 75$ & $40 \times 75$ & $30 \times 55$ \\
Beam2 & & $35 \times 75$ & $35 \times 65$ & $40 \times 70$ & $30 \times 60$ \\
Beam3 & & 40 & & 52 & $30 \times 60$ \\
BRB (area) & 0.69 & 0.42 & 0.87 & 0.72 & 0.92 \\
Period (s) & & & & 36 \\
\hline
\end{tabular}

TABLE 3: Selected ground motion records.

\begin{tabular}{|c|c|c|c|c|c|c|}
\hline Record & Date & Magnitude & Station & $P G A\left(\mathrm{~cm} / \mathrm{s}^{2}\right)$ & $P G V(\mathrm{~cm} / \mathrm{s})$ & $t_{D}(s)$ \\
\hline 1 & $19 / 09 / 1985$ & 8.1 & SCT & 178.0 & 59.5 & 34.8 \\
\hline 2 & $21 / 09 / 1985$ & 7.6 & Tlahuac deportivo & 48.7 & 14.6 & 39.9 \\
\hline 3 & $25 / 04 / 1989$ & 6.9 & Alameda & 45.0 & 15.6 & 37.8 \\
\hline 4 & $25 / 04 / 1989$ & 6.9 & Garibaldi & 68.0 & 21.5 & 65.5 \\
\hline 5 & $25 / 04 / 1989$ & 6.9 & SCT & 44.9 & 12.8 & 65.8 \\
\hline 6 & $25 / 04 / 1989$ & 6.9 & Sector popular & 45.1 & 15.3 & 79.4 \\
\hline 7 & $25 / 04 / 1989$ & 6.9 & Tlatelolco TL08 & 52.9 & 17.3 & 56.6 \\
\hline 8 & $25 / 04 / 1989$ & 6.9 & Tlatelolco TL55 & 49.5 & 17.3 & 50.0 \\
\hline 9 & $14 / 09 / 1995$ & 7.3 & Alameda & 39.3 & 12.2 & 53.7 \\
\hline 10 & $14 / 09 / 1995$ & 7.3 & Garibaldi & 39.1 & 10.6 & 86.8 \\
\hline 11 & $14 / 09 / 1995$ & 7.3 & Liconsa & 30.1 & 9.62 & 60.0 \\
\hline 12 & $14 / 09 / 1995$ & 7.3 & Plutarco Elías Calles & 33.5 & 9.37 & 77.8 \\
\hline 13 & $14 / 09 / 1995$ & 7.3 & Sector popular & 34.3 & 12.5 & 101.2 \\
\hline 14 & $14 / 09 / 1995$ & 7.3 & Tlatelolco TL08 & 27.5 & 7.8 & 85.9 \\
\hline 15 & $14 / 09 / 1995$ & 7.3 & Tlatelolco TL55 & 27.2 & 7.4 & 68.3 \\
\hline 16 & 09/10/1995 & 7.5 & Cibeles & 14.4 & 4.6 & 85.5 \\
\hline 17 & 09/10/1995 & 7.5 & CU Juárez & 15.8 & 5.1 & 97.6 \\
\hline 18 & 09/10/1995 & 7.5 & Centro urbano Presidente Juárez & 15.7 & 4.8 & 82.6 \\
\hline 19 & $09 / 10 / 1995$ & 7.5 & Córdoba & 24.9 & 8.6 & 105.1 \\
\hline 20 & 09/10/1995 & 7.5 & Liverpool & 17.6 & 6.3 & 104.5 \\
\hline 21 & 09/10/1995 & 7.5 & Plutarco Elías Calles & 19.2 & 7.9 & 137.5 \\
\hline 22 & 09/10/1995 & 7.5 & Sector popular & 13.7 & 5.3 & 98.4 \\
\hline 23 & $09 / 10 / 1995$ & 7.5 & Valle Gómez & 17.9 & 7.18 & 62.3 \\
\hline 24 & $11 / 01 / 1997$ & 6.9 & CU Juárez & 16.2 & 5.9 & 61.1 \\
\hline 25 & $11 / 01 / 1997$ & 6.9 & Centro urbano Presidente Juárez & 16.3 & 5.5 & 85.7 \\
\hline 26 & $11 / 01 / 1997$ & 6.9 & García Campillo & 18.7 & 6.9 & 57.0 \\
\hline 27 & $11 / 01 / 1997$ & 6.9 & Plutarco Elías Calles & 22.2 & 8.6 & 76.7 \\
\hline 28 & $11 / 01 / 1997$ & 6.9 & Est. \# 10 Roma A & 21.0 & 7.76 & 74.1 \\
\hline 29 & $11 / 01 / 1997$ & 6.9 & Est. \# 11 Roma B & 20.4 & 7.1 & 81.6 \\
\hline 30 & $11 / 01 / 1997$ & 6.9 & Tlatelolco TL08 & 16.0 & 7.2 & 57.5 \\
\hline
\end{tabular}

the maximum interstory drift in general tends to increase for all the building models as $S_{a}\left(T_{1}\right)$ also increases. In particular, the maximum interstory drift for a specific value of $S_{a}\left(T_{1}\right)$ is smaller in the case of the BRB buildings. For example, for the structural frame with 6 story levels and a value of $S_{a}\left(T_{1}\right)$ equal to $900 \mathrm{~cm} / \mathrm{s}^{2}$, the peak drift for the traditional RC6 model could be larger than 0.2 , while in the case of RC6$\mathrm{BRB}$, it is smaller than 0.1 . In other words, the uncertainty in the structural response prediction also tends to increase for larger values of $S_{a}\left(T_{1}\right)$, and this is especially true for the unbraced RC buildings. Figure 5 compares the standard deviation of the seismic response for the buildings with 3 stories at different performance levels in terms of the median maximum interstory drift. As it was expected, the values of the standard deviation are larger for the RC3 model in comparison with the RC3-BRB building. Finally, Figure 6 shows the seismic performance in terms of damage configuration of the BRBs for the model RC-BRB6 under record number one. It is observed that the structural damage is concentrated in the BRBs of the lower stories, as it is illustrated in the hysteretic curves of the braced for two intensity levels in terms of $S_{a}\left(T_{1}\right)$. It is important to say that for the selected scaling levels of the ground motion records, the $\mathrm{BRBs}$ have not reached their maximum capacity.

4.2. Structural Fragility. The structural fragility curves for the RC and RC-BRB buildings are computed in this section via equation (8) in terms of maximum interstory drift. The Mexico City Building Code and Bojórquez et al. [42] 


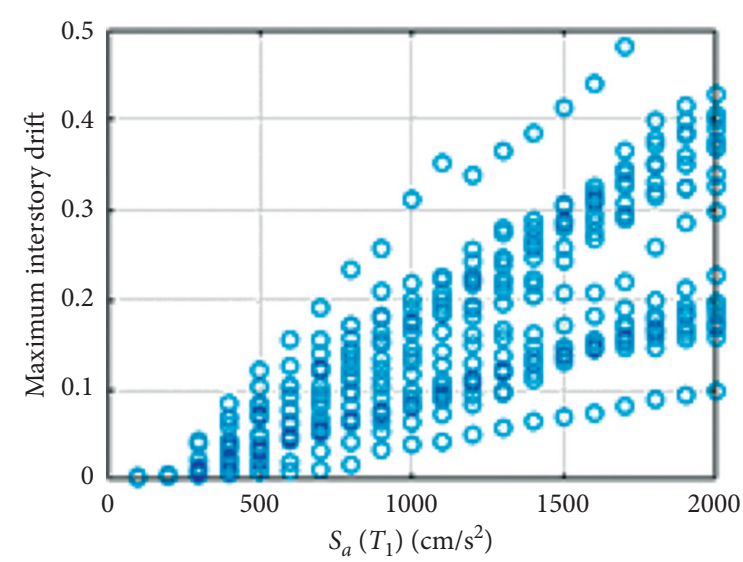

(a)

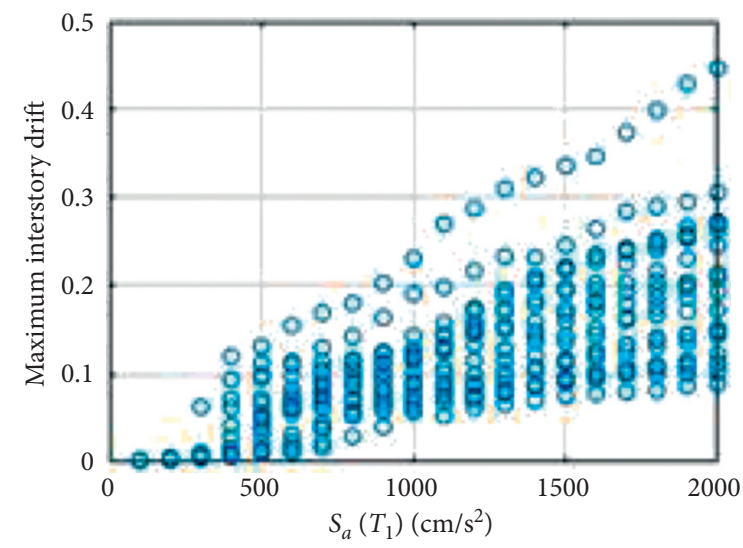

(c)

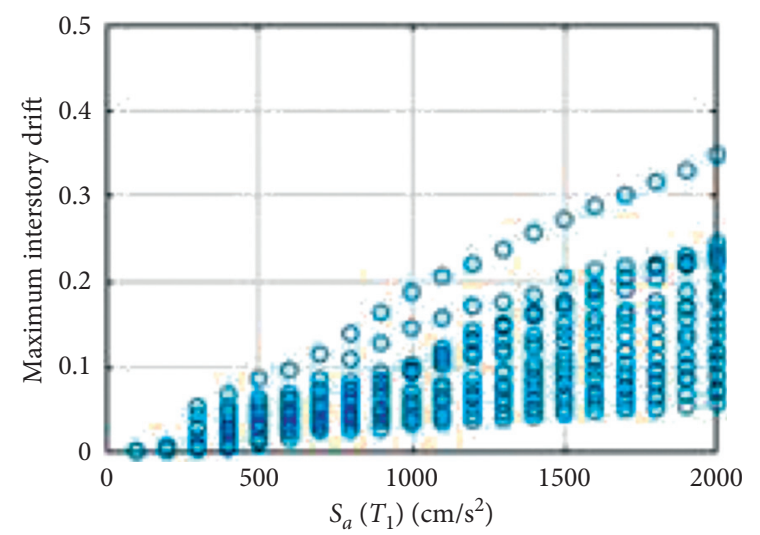

(e)

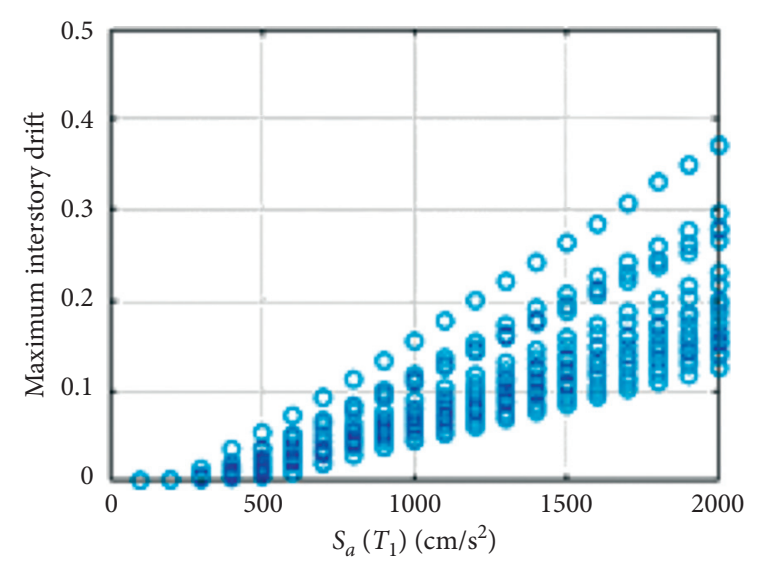

(b)

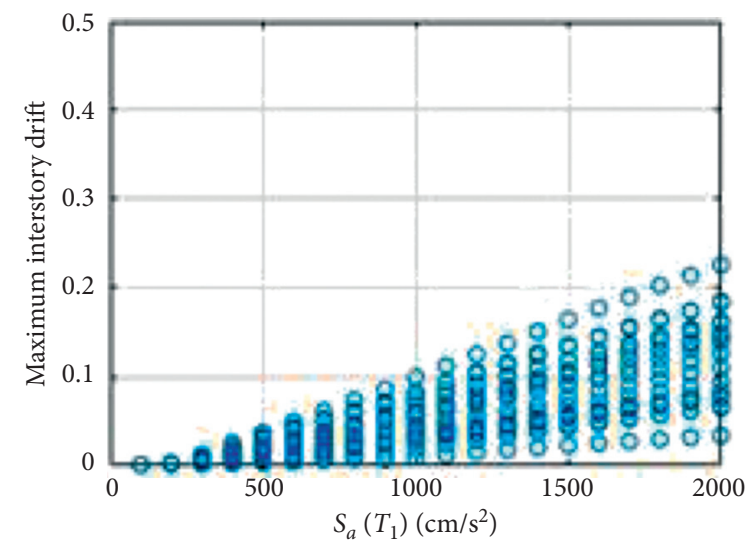

(d)

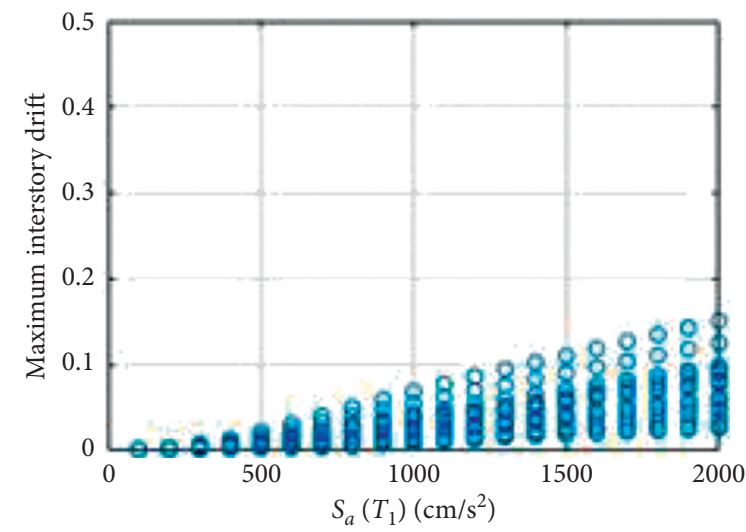

(f)

Figure 4: Incremental dynamic analysis curves for the buildings: (a) RC3, (b) RC3-BRB, (c) RC6, (d) RC6-BRB, (e) RC9, and (f) RC9-BRB.

indicated that the control of a maximum interstory drift of 0.02 guarantees a good seismic performance. Here, the fragility curves are computed and compared for both selected structural systems using the suggested 0.02 maximum interstory drift value. Figure 7 compares the seismic fragility for the 3,6, and 9 story levels of RC and RC-BRB buildings. The results suggest that the probability of exceeding the maximum interstory drift is larger for the traditional reinforced concrete frames for all the considered scaling levels in terms of spectral acceleration. For example, the probability to exceed a peak drift of 0.02 when $S_{a}\left(T_{1}\right)$ is equal to $1000 \mathrm{~cm} / \mathrm{s} 2$ is 0.8 for the RC3 building, while in the case of the equivalent RC3-BRB structure is about 0.45 , indicating that the performance of RC3-BRB is superior in comparison with RC3. The same conclusion is valid for the tallest buildings; in fact, as the level of stories of the buildings increases, the BRBs tend to decrease the probability of exceedance, in such a way that the effectiveness of buckling restrained braces is larger for taller buildings. 


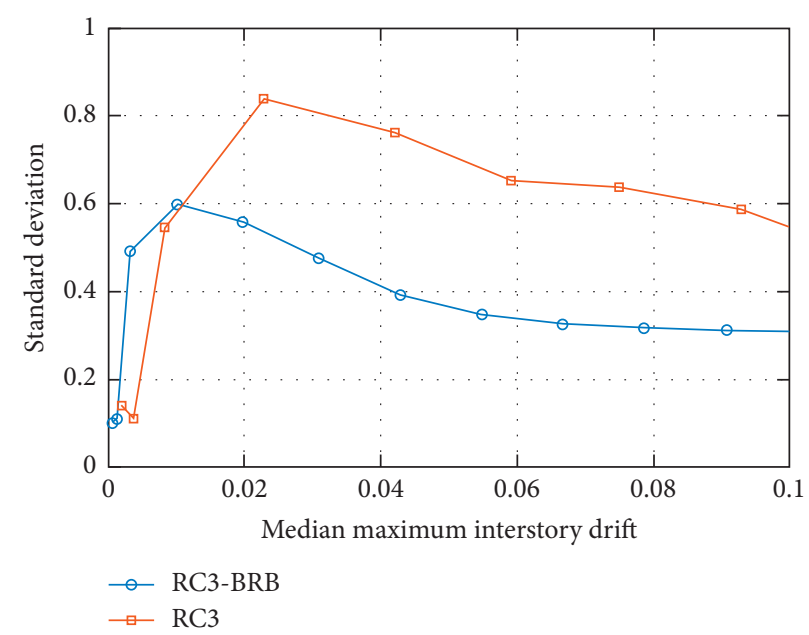

FIGURE 5: Comparison of the standard deviation at different performance levels in terms of the median maximum interstory drift value for the buildings RC3 and RC3-BRB.

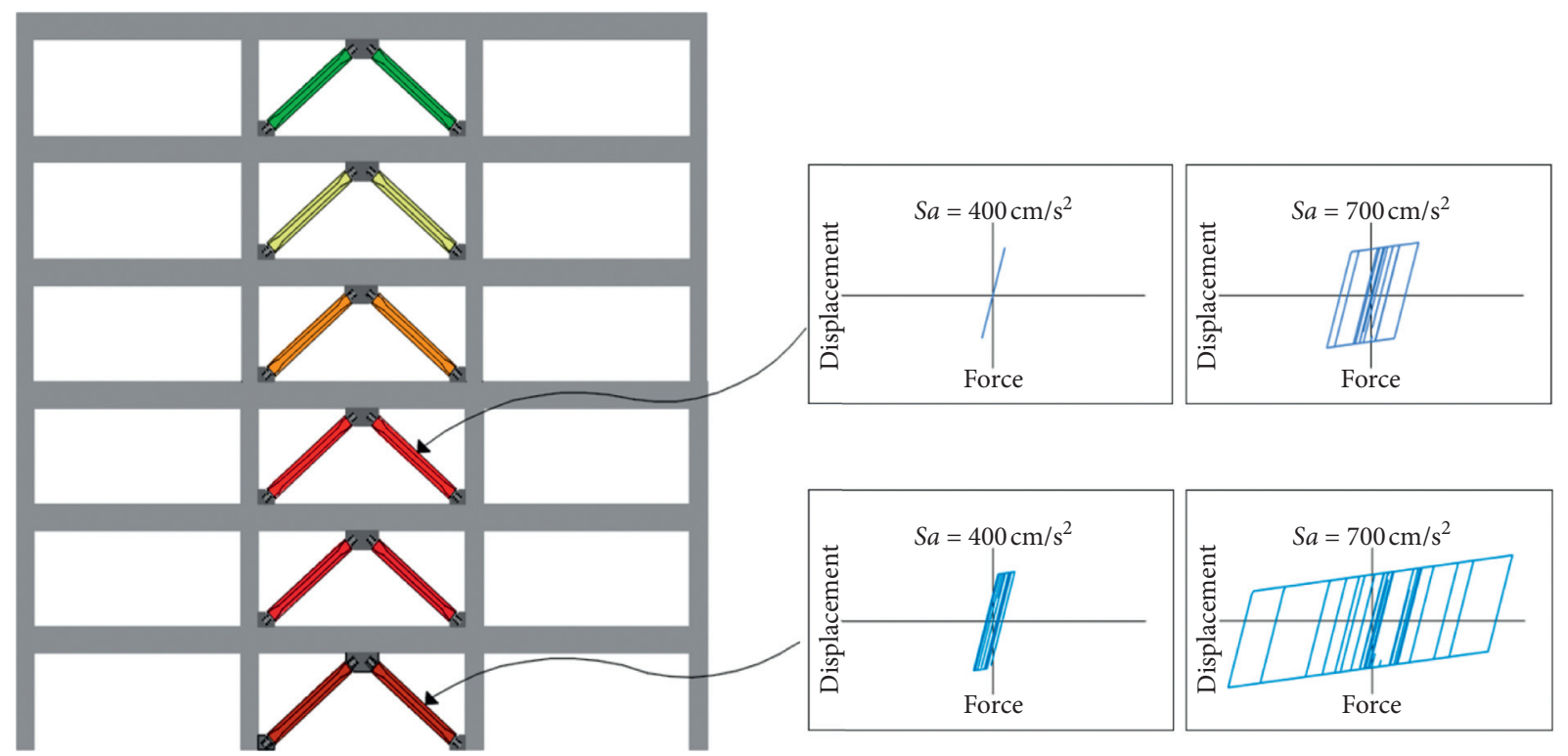

FIgure 6: Damage configuration of the RC6-BRB and hysteretic curves of the braces for two intensity levels.

4.3. Structural Reliability. The structural reliability is assessed by means of the fragility curves combined with the seismic hazard curves to calculate the mean annual rate of exceedance a maximum interstory drift threshold. For the present study, the spectral acceleration hazard curves corresponding to the first-mode period of vibration of each building and for the Secretaría de Comunicaciones $y$ Transportes (SCT) site in Mexico City were developed following the procedure suggested by Alamilla [44]. The seismic hazard curves in terms of peak interstory drift for the $\mathrm{RC}$ and the RC-BRB buildings are compared in Figure 8. The figure suggests that the mean annual rate of exceeding a specific value of maximum interstory drift is larger for the traditional reinforced concrete buildings. For this reason, the BRBs on reinforced concrete buildings increase considerably the structural reliability, which is valid for all the selected buildings. This is especially valid as the number of stories tend to increase as it was indicated in the case of the seismic fragility. The mean annual rate of exceedance a threshold equals 0.02 in terms of MID for the RC and RC$\mathrm{BRB}$ is given in Table 4. Note that it corresponds to target structural reliability levels of buildings designed according to the Mexican Building Code. Thus, the MARE values in terms of peak drift for the BRB buildings are considerably reduced in comparison to those of the RC structures provided by the Mexico City Building Code. In other words, it is observed that the values of the mean annual rates of exceedance for the RC-BRB systems are smaller than those of the traditional RC buildings. Note that there are other structural systems to improve the seismic reliability of buildings such as posttensioned connections [45]. The results indicate that the use of BRBs in buildings is a good solution in order to reduce 


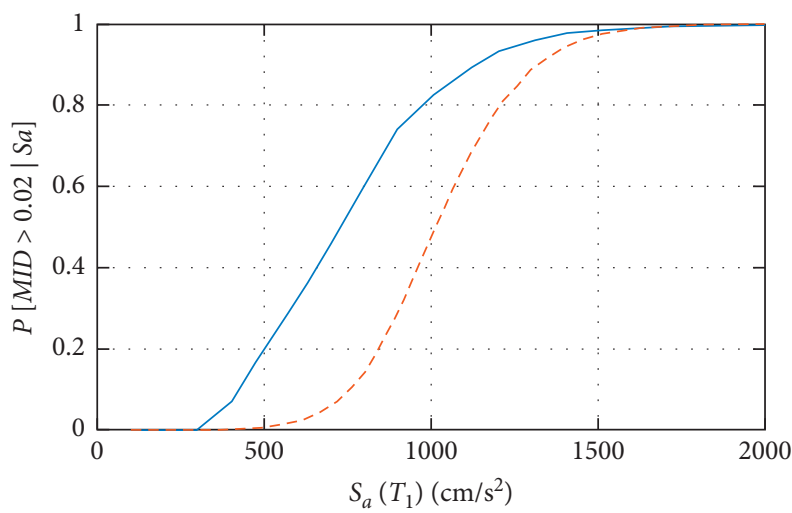

$-\mathrm{RC} 3$
$---\mathrm{RC} 3-\mathrm{BRB}$

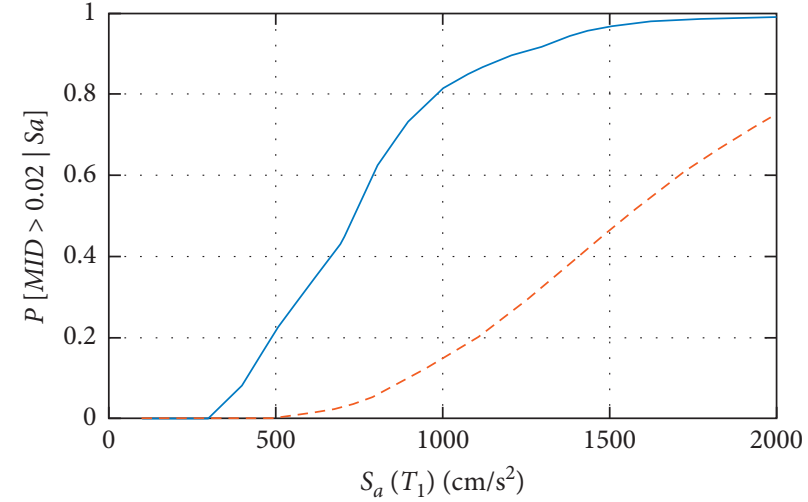

- RC6

--- RC6-BRB

(a)

(b)

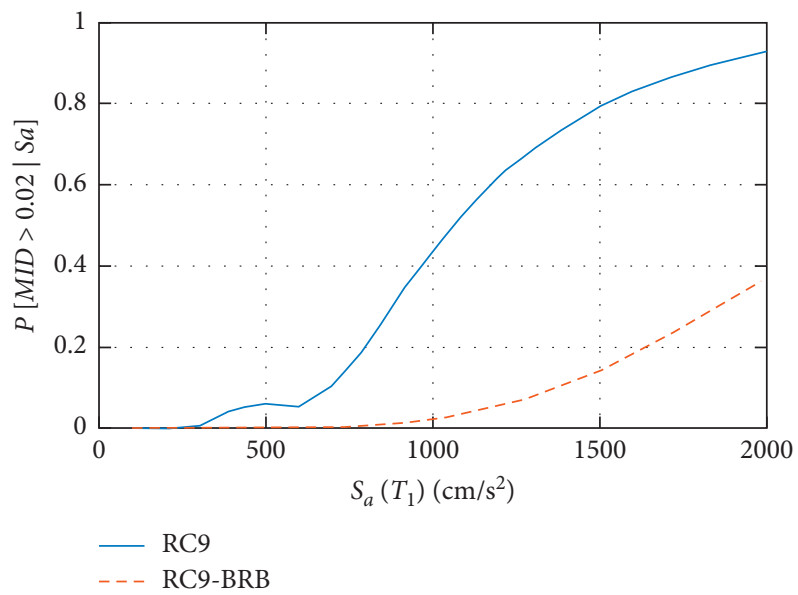

(c)

FIGURE 7: Fragility curves for maximum interstory drift and all the studied buildings.

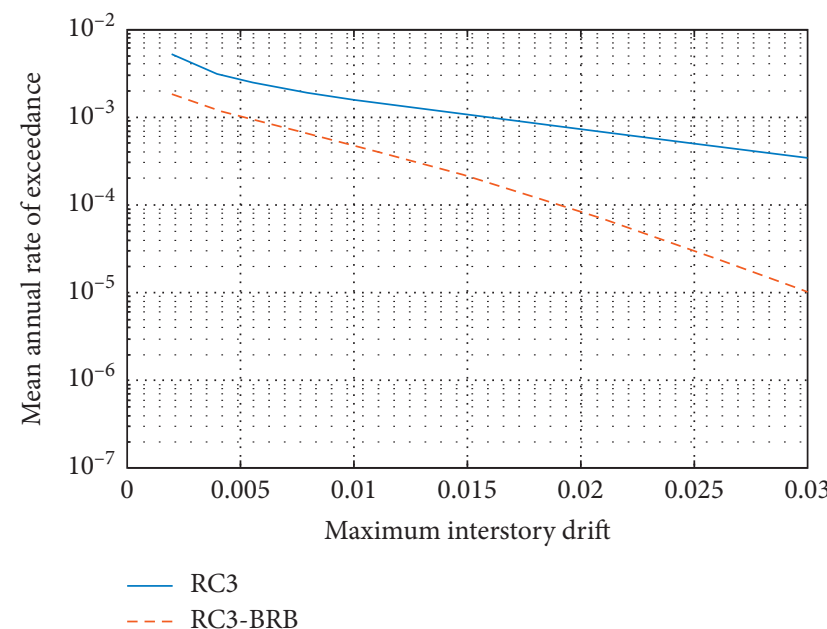

(a)

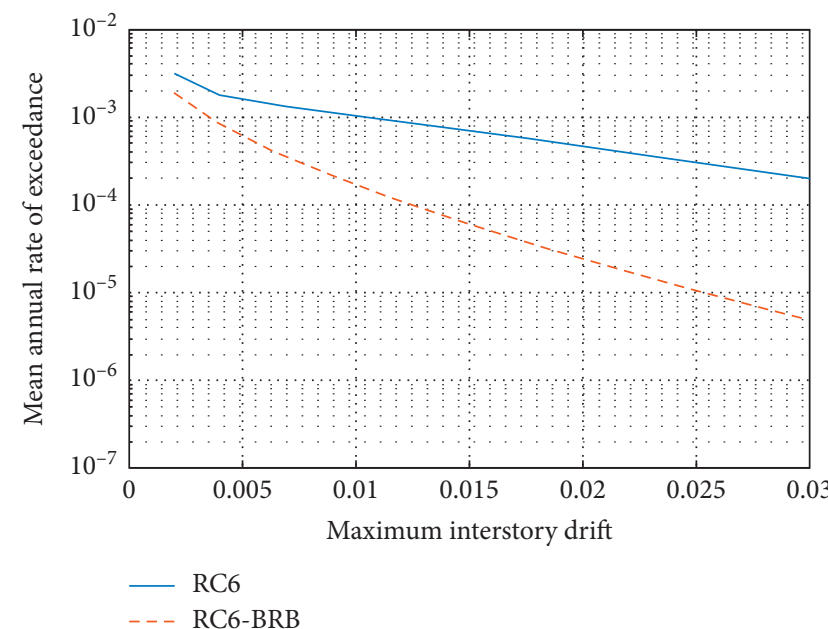

(b)

Figure 8: Continued. 


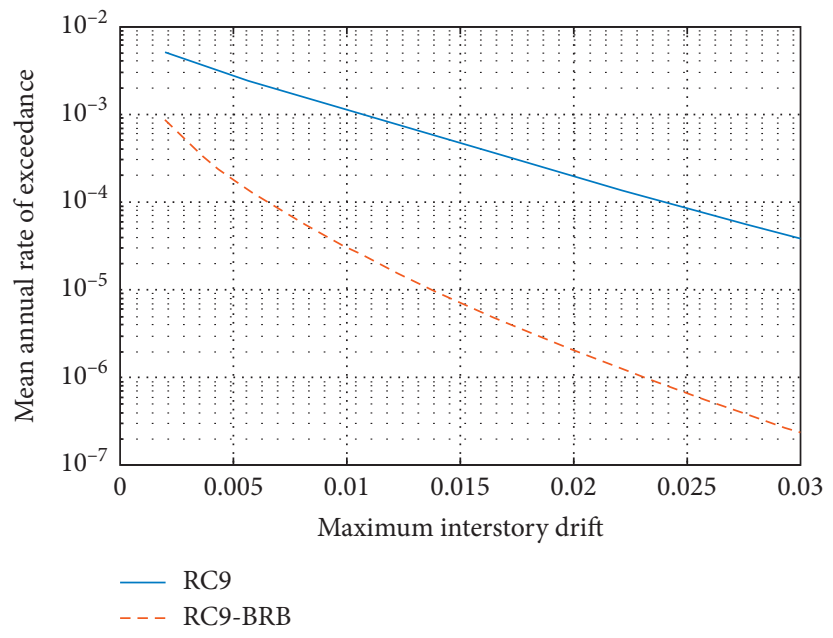

(c)

FIGURE 8: Comparison of the MID hazard curves for the RC and the RC-BRB buildings with (a) 3 stories, (b) 6 stories, and (c) 9 stories.

TABLE 4: Comparison of the mean annual rate of exceedance (MARE) values for the RC and RC-BRB buildings for a $M I D$ value equal to 0.02 .

\begin{tabular}{lccc}
\hline RC buildings & MARE for $M I D=0.02$ & RC-BRB buildings & MARE for $M I D=0.02$ \\
\hline RC3 & 0.00072 & RC3-BRB & 0.000084 \\
RC6 & 0.00046 & RC6-BRB & 0.000024 \\
RC9 & 0.00019 & RC9-BRB & 0.0000024 \\
\hline
\end{tabular}

peak drift demands of traditional structures located in high seismic zones.

\section{Conclusions}

The seismic performance of three traditional reinforced concrete buildings and equivalent structures with BRBs is assessed through incremental dynamic analysis, seismic fragility, and structural reliability. For this aim, the maximum interstory drift was selected as engineering demand parameter. The buildings were subjected to several narrowband motions recorded at soft soil of Mexico City. The results indicate that the maximum interstory drift demand is smaller in the case of the RC-BRB buildings in comparison with the reinforced concrete structures. Moreover, the uncertainty in the structural response prediction also tends to decrease when the BRBs are used in the RC buildings. This is reflected in the fragility analysis where the probability of exceeding the maximum interstory drift is larger for the traditional reinforced concrete frames for all the considered scaling levels in terms of $S_{a}\left(T_{1}\right)$. Finally, the MARE, a specific value of maximum interstory drift, is larger for the traditional reinforced concrete buildings in comparison with the BRB buildings. For this reason, the BRBs on RC buildings increase the structural reliability for all the buildings under consideration. This is particularly valid for the tallest buildings studied. In conclusion, the use of BRBs is a good solution to obtain safer buildings or in order to reduce peak drift demands of traditional structures under strong earthquake ground motions.

\section{Data Availability}

The data used to support the findings of this study are available from the corresponding author upon request.

\section{Conflicts of Interest}

The authors declare that there are no conflicts of interest regarding the publication of this paper.

\section{Acknowledgments}

The financial support given by the Universidad Autónoma de Sinaloa under grant PROFAPI is appreciated. The authors express their gratitude to the Consejo Nacional de Ciencia $y$ Tecnología (CONACYT) in Mexico for funding the research reported in this paper under grant Ciencia Básica 287103 and for the scholarships given to the PhD students. The support of the UNAM-DGAPA-PAPIIT under project no. IN100320 is appreciated.

\section{References}

[1] H. Krawinkler and A. Gupta, "Deformation and ductility demands in steel moment frame structures," Stability and Ductility of Steel Structures, vol. SDSS'97, pp. 1825-1830, 1998.

[2] A. Khampanit, S. Leelataviwat, J. Kochanin, and P. Warnitchai, "Energy-based seismic strengthening design of non-ductile reinforced concrete frames using buckling-restrained braces," Engineering Structures, vol. 81, pp. 110-122, 2014. 
[3] H. Guerrero, T. Ji, A. Escobar, and A. Terán-Gilmore, "Effects of buckling-restrained braces on reinforced concrete precast models subjected to shaking table excitation," Engineering Structures, vol. 163, pp. 294-310, 2018.

[4] J. Osteraas and H. Krawinkler, "“The Mexico earthquake of September 19, 1985-behavior of steel buildings," Earthquake Spectra, vol. 5, no. 1, pp. 51-88, 1989.

[5] H. Kim, Seismic evaluation and upgrading of braced frame structures for potential local failures, PhD thesis, p. 290, UMCEE 92-24, Dept. of Civil Engineering and Environmental Engineering, Univ. of Michigan, Ann Arbor, Michigan, 1992.

[6] R. Tremblay, A. Filiatrault, P. Timler, and M. Bruneau, "Performance of steel structures during the 1994 Northridge earthquake," Canadian Journal of Civil Engineering, vol. 22, no. 2, pp. 338-360, 1995.

[7] Architectural Institute of Japan and Steel Committee of Kinki Branch, Reconnaissance Report on Damage to Steel Building Structures Observed from the 1995 Hyogoken-Nanbu (Hanshin/Awaji) Earthquake, p. 167, AIJ, Tokyo, 1995.

[8] T. Hisatoku, "Reanalysis and repair of a high-rise steel building damaged by the 1995 Hyogoken-Nanbu earthquake," in Proceedings, 64th Annual Convention, Structural Engineers Association of California, pp. 21-40, Structural Engineers Association of California, Sacramento, CA, USA, October 1995.

[9] R. Tremblay, A. Filiatrault, M. Bruneau et al., "Seismic design of steel buildings: lessons from the 1995 Hyogo-ken Nanbu earthquake," Canadian Journal of Civil Engineering, vol. 23, no. 3, pp. 727-756, 1996.

[10] R. Sabelli, S. Mahin, and C. Chang, "Seismic demands on steel braced frame buildings with buckling-restrained braces," Engineering Structures, vol. 25, no. 5, pp. 655-666, 2003.

[11] C. M. Uang and M. Nakashima, "Steel buckling-restrained braced frames," Earthquake Engineering, Recent advances and applications, CRC Press, Boca Raton, FL, USA, chapter 16, 2004.

[12] C. M. Uang and M. Nakashima, Earthquake Engineering: From Engineering Seismology to Performance Based Engineering, CRC Press LLC, Boca Raton, FL, USA, 2004.

[13] Q. Xie, "State of the art of buckling-restrained braces in Asia," Journal of Constructional Steel Research, vol. 61, pp. 727-748, 2005.

[14] G. Della Corte, M. D’Aniello, R. Landolfo, and F. Mazzolani, "Review of steel buckling restrained braces," Steel Construction, vol. 4, no. 2, pp. 85-93, 2011.

[15] S. Kiggins and C. M. Uang, "Reducing residual drift of buckling-restrained braced frames as a dual system," Engineering Structures, vol. 28, pp. 1525-1532, 2006.

[16] M. Bosco, E. Marino, and P. Rossi, "Design of steel frames equipped with BRBs in the framework of Eurocode 8," Journal of Constructional Steel Research, vol. 113, pp. 43-57, 2015.

[17] A. Lago, D. Trabucco, and A. Wood, "Case studies of tall buildings with dynamic modification devices," Damping Technologies for Tall Buildings, Elsevier, Amsterdam, Netherlands, chapter 8, 2018.

[18] G. Palazzo, F. Lopez-Almansa, X. Cahis, and F. Crisafulli, "A low-tech dissipative buckling restrained brace. Design, analysis, production and testing," Engineering Structures, vol. 31, pp. 2152-2161, 2009.

[19] Mexico City Building Code 2017.

[20] K. Deb, Multi-objective Optimization Using Evolutionary Algorithms, John Wiley \& Sons, Chichester-New YorkWinheim-Brisbane-Singapore-Toronto, 2001.
[21] K. Deb, A. Pratap, S. Agarwal, and T. Meyarivan, “A fast and elitist multiobjective genetic algorithm: NSGA-II," IEEE Transactions on Evolutionary Computation, vol. 6, no. 2, pp. 182-197, 2002.

[22] J. Avilés and L. Pérez-Rocha, "Damage analysis of structures on elastic foundation," Journal of Structural Engineering, vol. 133, no. 10, pp. 1453-1461, 2007.

[23] S. Abdel, M. Ahmed, and T. Alazrak, "Evaluation of soilfoundation-structure interaction effects on seismic response demands of multi-story MRF buildings on raft foundations," International Journal of Advanced Structural Engineering, vol. 7, no. 1, pp. 11-30, 2014.

[24] A. Wada, E. Saeki, T. Takeuchi, and A. Watanabe, Development of Unbounded Brace, Nippon Steel Corporation Building Construction and Urban Development Division, Tokyo, Japan, 1998.

[25] A. Terán-Gilmore and N. Virto-Cambray, "Preliminary design of low-rise buildings stiffened with buckling restrained braces by a displacement-based approach," Earthquake Spectra, vol. 25, no. 1, pp. 185-211, 2009.

[26] H. Guerrero, T. Ji, and J. Escobar, "Experimental studies of a steel frame model with and without buckling-restrained braces," Revista de Ingeniería Sísmica, vol. 95, pp. 33-52, 2016.

[27] R. Rahnavard, M. Naghavi, M. Aboudi, and M. Suleiman, "Investigating modeling approaches of buckling-restrained braces under cyclic loads," Case Studies in Construction Materials, vol. 8, pp. 476-488, 2018.

[28] A. Almeida, R. Ferreira, J. Proenca, and A. Gago, "Seismic retrofit of RC building structures with buckling restrained braces," Engineering Structures, vol. 130, pp. 14-22, 2017.

[29] R. Tremblay, P. Bolduc, R. Nevilley, and R. DeVall, "Seismic testing and performance of buckling restrained bracing systems," Canadian Journal of Civil Engineering, vol. 33, pp. 183-198, 2006.

[30] A. Terán-Gilmore and J. Ruiz-García, "Comparative seismic performance of steel frames retrofitted with buckling buckling-restrained braces through the application of force-based and displacement-based approaches," Soil Dynamic and Earthquake Engineering, vol. 31, no. 3, pp. 478-490, 2011.

[31] J. Holland, Adaptation in Natural and Artificial Systems. An Introductory Analysis with Applications to Biology, Control and Artificial Intelligence, University of Michigan Press, Ann Arbor, Mich, 1975.

[32] M. Barraza, E. Bojórquez, E. Fernández-González, and A. Reyes-Salazar, "Multi-objective optimization of structural steel buildings under earthquake loads using NSGA-II and PSO," KSCE Journal of Civil Engineering, vol. 21, pp. 488-500, 2017.

[33] M.-D. Yang, M.-D. Lin, Y.-H. Lin, and K.-T. Tsai, "Multiobjective optimization design of green building envelope material using a non-dominated sorting genetic algorithm," Applied Thermal Engineering, vol. 111, pp. 1255-1264, 2017.

[34] S. Bakhshinezhad and M. Mohebbi, "Multi-objective optimal design of semi-active fluid viscous dampers for nonlinear structures using NSGA-II," Structures, vol. 24, pp. 678-689, 2020.

[35] H. Leyva, E. Bojórquez, J. Bojórquez et al., "Earthquake design of reinforced concrete buildings using NSGA-II," Advances in Civil Engineering, vol. 2018, Article ID 5906279, 11 pages, 2018.

[36] E. Bojórquez and S. E. Ruiz, "Strength reduction factors for the valley of Mexico taking into account low cycle fatigue effects," in Proceedings of $13 \underline{o}$ World Conference on 
Earthquake Engineering, Vancouver, BC, Canadapaper 516, Vancouver, BC, Canada, August 2004.

[37] A. Terán-Gilmore and J. O. Jirsa, "Energy demands for seismic design against low cycle fatigue," Earthquake Engineering and Structural Dynamics, vol. 36, pp. 383-404, 2007.

[38] M. D. Trifunac and A. G. Brady, "A study of the duration of strong earthquake ground motion," Bulletin of the Seismological Society of America, vol. 65, no. 3, pp. 581-626, 1975.

[39] D. Vamvatsikos and C. A. Cornell, "Incremental dynamic analysis," Earthquake Engineering and Structural Dynamics, vol. 31, no. 3, pp. 491-514, 2002.

[40] G. G. Deierlein, Overview of a Comprehensive Framework for Performance Earthquake Assessment, Report PEER 2004/05, pp. 15-26, Pacific Earthquake Engineering Center, Berkeley, CF, USA, 2004

[41] E. Bojórquez and J. Ruiz-García, "Residual drift demands in moment-resisting steel frames subjected to narrow-band earthquake ground motions," Earthquake Engineering and Structural Dynamics, vol. 42, pp. 1583-1598, 2013.

[42] E. Bojórquez, A. Terán-Gilmore, S. E. Ruiz, and A. ReyesSalazar, "Evaluation of structural reliability of steel frames: interstory drift versus plastic hysteretic energy," Earthquake Spectra, vol. 27, no. 3, pp. 661-682, 2011.

[43] E. Bojórquez and I. Iervolino, "Spectral shape proxies and nonlinear structural response," Soil Dynamics and Earthquake Engineering, vol. 31, no. 7, pp. 996-1008, 2011.

[44] J. L. Alamilla, Reliability-based Seismic Design Criteria for Framed Structures, PhD Thesis, Universidad Nacional Autónoma de México, UNAM, Mexico, 2001.

[45] E. Bojórquez, A. López-Barraza, A. Reyes-Salazar et al., "Improving the structural reliability of steel frames using posttensioned connection," Advances in Civil Engineering, vol. 2019, Article ID 8912390, 10 pages, 2019. 